\title{
A Study on the Multimodal Metaphorical and Metonymical Framing in Xi'an City Image Promotional Video
}

\author{
Yanqin Cao ${ }^{1, \text { a }}$, Zhaohong Yao ${ }^{2, b}$ \\ ${ }^{1}$ School of Humanities and International Education, Xi'an Peihua University, Chang'an Campus, Xi’an, \\ China \\ ${ }^{2}$ School of Foreign Languages, Xidian University, Chang' an Campus, Xi'an, China \\ acatherinecyq@163.com, brichardyzh@163.com
}

Keywords: Xi'an City Image Promotional Video; multimodal metaphors and metonymies; framing theory

\begin{abstract}
As a linguistic phenomenon, the generation and use of multimodal metaphors and metonymies in $\mathrm{Xi}$ 'an City Image Promotional Video are influenced by the socio-cultural context and situational context, which is the embodiment of human cognitive mode. By studying the multimodal discourse of Xi'an City Image Promotional Video from the perspective of framing theory, it is hoped that a better understanding of the conceptual connotation, cognitive characteristics and operation mode of the multimodal metaphors and metonymies can be achieved. Meanwhile, the mechanisms and functions of the generation and understanding of metaphors and metonymies can be realized. Therefore, this study is conducive to creating a friendlier and warmer communication environment, improving the taste and aesthetic effect of the publicity discourse, gaining the conscious approval of the public, and shaping a positive and open city image.
\end{abstract}

\section{Introduction}

The image of a city is the spirit and style of the whole city, including the overall appearance and characteristics of the city, the values, spirit and culture of the city residents. City image publicity discourse is the visiting card of a modern city, and also a symbol of the city's historical accumulation and cultural connotation. The study of city image publicity discourse by scholars at home and abroad involves various disciplines such as media studies, art design, culturology, semiotics, linguistics, sociology and economics, etc. In the field of linguistics, the study mainly focuses on the following aspects: critical discourse analysis of city image publicity discourse, based on the three meta-functions of language, analyzes and explores the ideology implied in the city image publicity discourse and the relationship between city image publicity discourse and ideology from the perspective of critical analysis [1]; translation studies of city image publicity discourse, represented by Huang Shujun [2], which were guided by the theory of ecological translation, translated and appreciated Wuhan City Image Promotional Video from three dimensions of language, culture and communication. Pan Yan-yan [3] discussed the persuasion effect of metaphor and metonymy on achieving discourse cohesion and coherence and shaping China's national image and new national spirit in the Documentary China's National Image Promotion: Perspectives. However, these researches fail to explain the conceptual features and cognitive mechanism of the generation and understanding of metaphors and metonymies in the publicity discourse.

In today's era of multimodal communication, multimodal discourses composed of images, voices, texts, media compositions, shapes, and other symbols have become an important window to publicize city image and multimodal metaphors have been widely used to fully arouse the senses, convey messages and exchange emotions. According to contemporary cognitive linguistics, metaphor is conceptual in nature, and its expression forms are not confined to language symbols. Other media, such as sound, color, line and spatial layout, can also be used to construct and express conceptual metaphors. The multimodal metaphor refers to a metaphorical phenomenon in which 
two or more modes are employed to represent the mapping from the source domain to the target domain, mainly realized by audio and visual modes. Specifically, there are five physical forms of multimodal metaphors: written text, spoken language, static or dynamic images, music, non-verbal sounds, and gestures.

From the perspective of cognitive science, this paper attempts to analyze multimodal metaphors and metonymies in Xi'an City Image Promotional Video, and explore the underlying metaphorical deep frames, in order to gain an in-depth understanding of how the City Image Promotional Video draws on the widespread and well-established conceptual metaphors and metonymies to convey the intention of the producer and win the audience's recognition.

\section{Theoretical Framework}

With the cognitive revolution in the 1980s, metaphor and metonymy are no longer confined to the category of rhetoric. They are defined as thinking means, behavior modes and cognitive tools that human beings live by. With the advancement of metaphor research, Lakoff, the founder of cognitive linguistics, put forward framing theory on the basis of the concept of frame proposed by Goffman [4] and Fillmore [5]. Lakoff [6] believes that the audience always employs the frame, metaphor and other thinking blocks based on the body and the interaction between the body and the surrounding world for discourse understanding. Frame is a deep-rooted psychological structure that determines how we view the world [7]. If the metaphorical structure in city image promotional video is consistent with the preset frame in the public's brain, it will be easier for them to understand and accept, thus improving the publicity effect.

\section{Analysis of Multimodal Metaphors and Their Frames in Xi'an City Image Promotional Video}

\subsection{Personification Metaphor}

(1) Here is condensed Chinese people's genetic heritage.

Xi'an City Image Promotional Video widely used the personification metaphor of Xi'an IS HUMAN, which endows the city with human characters, emotions and values. Personification metaphors have affinity and vivid images, which can make the audience understand the target domain (city) and generate empathy for the audience [8]. In example (1), language expression reflects the conceptual metaphor Xi'an IS GENE based on the conceptual metaphor of CHINESE CIVILIZATION IS HUMAN. Knowledge of biology tells us that genes enable mothers to faithfully reproduce their own characteristics to their offspring, thus ensuring the continuity and stability of the traits of life. The use of this metaphor reveals the most essential national spirit and cultural tradition of the Chinese nation carried by Xi'an, which is the foundation of the Chinese nation. Just like defining human nature by inherited genes, $\mathrm{Xi}$ 'an is the root of the Chinese nation.

(2) This is an inclusive Xi'an, reserved and broad. This is a lofty, dignified and unaffected Xi'an.

The personification metaphor of Xi'an IS HUMAN endows Xi'an with human characteristics, facilitating the public to understand and experience the city's appearance and style. As the capital of thirteen dynasties, Xi'an enjoys a high status with a long-standing history, but she was tolerant, unpretentious and unadorned. At the same time, the conceptual metaphor activates the frame of containment. According to historical records, as early as the Western Han Dynasty, Emperor Wu sent Zhang Qian to the Western Region and opened up the Silk Road starting from Xi'an which became the bridge to connect the East and the West. Xi' an was renowned as the world's political, economic, cultural, scientific, technological and military center in the heyday of the Tang Dynasty more than one thousand years ago. The culture of the Tang Dynasty was characterized by being compatible with and integrated with various ethnic groups and religions, forming an open and inclusive international culture. Enjoying a long-established tradition of opening-up and tolerance, $\mathrm{Xi}$ 'an, in the context of China's reform and opening-up to the outside world, welcome enterprises and friends from home and abroad to invest and develop their business, reflecting the broad mind 
and bearing which are in conformity with the values of tolerance and understanding and the frame of tolerance formed since a long time in the Chinese culture, thus being more likely to win the audience's recognition and support.

\subsection{Plant Metaphor}

$\mathrm{Xi}$ 'an is endowed with the ancient root of the Chinese nation.

It contains the conceptual metaphor of NATION IS PLANT. The roots help plants absorb nutrients and water from the soil and withstand natural disasters. The development of a nation is also based on national cultural traditions. As the most authentic source of strength for the development of the Chinese nation, Xi'an, the birthplace of the Chinese nation in the Yellow River Valley, carries profound historical and cultural origins and endows the development of our nation with fundamental Chinese characteristics and Chinese spirit in the new era.

\subsection{Animal Metaphor}

Modern equipment manufacturing industry and high-tech industry spread out both wings to achieve rapid development

Here, the city is compared to a bird. Birds can fly only when they have wings. Modern equipment manufacturing and high-tech industry have become the pillar industry of Xi'an just like the wings of birds, which plays an essential role in the city's economic development. It is not difficult to understand the meaning of metaphor by combining the situational context and content of the City Image Promotional Video, as well as the information interaction between the public as discourse participants and the producer.

\subsection{Container Metaphor}

The scientific concept of development infuses new life into the city

Container metaphor is a frequently used conceptual metaphor, in which the city of Xi'an is compared to a container. In the mean time, the entity metaphor SCIENTIFIC CONCEPT OF DEVELOPMENT IS NUTRIENTS is employed. The combination of the two conceptual metaphors conveys the message: as a man needs the nutrition offered by the food for his survival, the concept of scientific development provided nourishment for the city's development, showing the correct and advanced development path advocated by Xi'an municipal government.

\subsection{Journey metaphor}

The journey metaphor is also a conceptual metaphor throughout the Promotional Video, which effectively connects different parts of the video and conveys the development process and vision of Xi'an. The journey metaphor is the universal life experience of all nationalities in the world. The journey has its starting point, hikers, direction and destination, and the development of the city also has its history, partners, direction and goal. This systematic structural metaphor enables the audience to understand the development of the city from the perspective of the familiar concept of journey.

(1) From the myth of $\mathrm{Nu}$ Wa repairing the sky and Cang Jie inventing characters, courtesy of the Zhou Dynasty and governance of the Qin Dynasty to the strength and prosperity, countless ancient myths, historical books and classics, unearthed cultural relics and ancient historical sites in this land tell of his brilliance and vicissitudes.

The Promotional Video also employed the conceptual metaphor of THE DEVELOPMENT OF CHINESE CIVILIZATION IS A JOURNEY. Xi'an, the capital of such Chinese feudal dynasties as Zhou, Qin, Han, Tang, has also witnessed such great historical events of $\mathrm{Nu}$ Wa repairing the sky and Cang Jie inventing characters at the beginning of the Chinese nation during the development of the Chinese civilization, embodying and representing the wealth of the Chinese cultural heritage. Therefore, the encyclopedic knowledge about Chinese history is stimulated in public's mind, and the impression was enhanced by cultural symbols with characteristics of Xi'an.

(2) In the new century, Xi'an is bringing today's glory into space, where Asia's largest aviation city and China's space city are rising. 
The journey metaphor, based on the image schema "source-path-goal", materializes the abstract concept of honor through images of launching rockets, and the rocket flying into space is also symbolizing the rapid progress of Xi'an. In the following picture, the aircraft flying in the sky also reflects the takeoff of Xi'an in the new century. The scene of a sun rising implies the metaphor of THE CITY IS THE RISING SUN IN THE EAST. Based on people's daily life experience, it is easy for the audience to understand that the rising sun indicates the driving force for the city's development brought by the rapid growth of aviation industry in Xi'an and indicates the vibrant future of the city.

(3) The fragrance of the ancient city lingers, and the modern atmosphere is blended and stored in the bosom of Xi'an. Tradition and innovation, development and protection, man and nature, man and man are in harmony with each other.

The City Wall of Xi'an, set against a backdrop of modern skyscrapers, is seen at the foreground of the public's eye. One young man, dressed in a white traditional Chinese martial arts costume, waves a red ribbon and leaps forward, reflecting the integration of tradition and modernity. The red ribbon in Chinese culture is a symbol of fortune and prosperity. Consequently, the picture of the dancing ribbon reflects the conceptual metaphor CITY'S DEVELOPMENT IS JOURNEY, activating the harmony frame in Chinese culture. Since ancient times, Chinese traditional philosophy has been in the pursuit of the harmony of man and nature, man and society, thus forming the values and code of conduct with "harmony" as the core which has become the Chinese national spirit.

(4) Xi'an has made a great leap forward towards the goal of becoming an international modern metropolis with historical and cultural characteristics.

Accompanied by passionate music, images of rippling lake, crisscross of highway system appeared in the public's eye, the commentary "Xi' an has made a great leap forward towards the goal of becoming an international modern metropolis with historical and cultural characteristics" embodies the conceptual metaphor THE DEVELOPMENT OF A CITY IS JOURNEY and reveals the prospects of the development of Xi'an in the new century. Meanwhile, the frame of endeavor is activated, which is in consistency with the value orientation of "work hard and strive upward" preset by the public, and are liable to gain the public's recognition [9].

(5) Today, Xi'an, a romantic, international, market-oriented, humanized and ecological flourishing city, is changing from a vision to reality. People in Xi'an are continuing to create a glorious future for the glory of history and today.

Beginning with a review of the glorious history of Xi'an, the Promotional Video exhibits the transformation of the city's infrastructure, economy, environment, culture in the process of modernization, embodying the conceptual metaphor THE DEVELOPMENT OF A CITY IS JOURNEY which has played an important role in discourse cohesion and coherence. Thus, the whole Promotional Video has distinct theme, easy for the audience to understand and accept, fulfilling a favorable publicity effect. In the video's end, a group of lovely children appear on the screen, which represents the hope of the future Xi'an. The children's smiling faces represent the brilliant future of Xi'an, and they are holding paintings with the colorful landmark of the Wild Goose Pagoda, which also represents personalized hope for Xi'an cherished by all children. The pictures activate the optimism frame and reflect the hope, innovation and vitality. The picture with two children holding hands contains the frame of cooperation and friendship, showing that people in Xi'an are full of confidence in the city's development. The future development of Xi'an requires people from all walks of life at home and abroad to join hands and cooperate for win-win results to build a beautiful and prosperous Xi'an. At the same time, the vigorous growing tree, the smiling sun and the clouds all express the harmony frame. The urban construction of Xi'an adheres to the concept of sustainable ecological development and pursues to create a beautiful vision of harmony between men, men and nature.

\subsection{Stage metaphor}

A city is like a living and flowing history, where the heart and history can be used for dialogue, 
and the eyes and culture can be embraced.

Set against the backdrop of a modern high-rise building, the performance images of two actors of Shaanxi Opera in costume embody the conceptual metaphor Xi'an IS A BIG STAGE, which implies that Xi'an residents are performing a wonderful drama of life and composing a magnificent symphony in the grand stage of modernization.

\section{Analysis of Multimodal Metonymies and Their Frames In Xi'an City Image Promotional Video}

\subsection{The typical features stands for the entity itself}

\subsubsection{The terra cotta warriors stands for the city}

At the beginning of the Promotional Video, the face of the world-famous landmark and symbol of Xi'an - Terra Cotta Warriors and Horses became gradually prominent, which introduces the commentary of glorious Xi'an. The Terra Cotta Warriors, a specific perceived cultural symbol, provides mental access to the abstract concept of the long-standing history and culture of the city realized by the conceptual metonymy THE TYPICAL FEATURES STANDS FOR THE ENTITY ITSELF. Conforming to the principle of prominence of human's cognition, this metonymy immediately activates the related cultural knowledge and cognitive environment in the brains of the audience, which are apt to be accepted by the audience.

\subsubsection{The thirteen imperial seals were overlaid on this thick land}

As a symbol of the imperial power of China's feudal dynasties, imperial seals have been wellknown among audience in Chinese cultural context. Combined with the commentary, the golden imperial seal in the picture reflects the metonymy operation of referring to things by typical features, highlighting the supremacy of Xi'an as the ancient capital of 13 dynasties in Chinese history.

\subsubsection{Excellence uttered by many Chinese and foreigners}

Facing the arts, crafts and rare antiques in the streets, Xi'an residents speak "it's wonderful" in Shaanxi Dialect, and foreign tourists also learn to thumb and imitate speaking Shaanxi Dialect. The audience can feel people's feelings and attitudes from the words and facial expression of the people, reflecting people's appreciation for the culture of the city. Besides, foreigners are deeply impressed by the rich culture of Xi'an and they speak highly of the city, conveying the message that Xi'an is opening arms towards the world with an open and inclusive attitude and gradually being known and recognized by the world. Looking back on the image of the international metropolis of ancient Xi'an, this metonymy plays a role of discourse coherence and theme highlighting, and constructs a positive city image.

\subsubsection{Chinese calligraphy is pleasant to look at.}

Chinese ancient paintings commonly used vermilion, cyan, so the painting is called "Dan qing." Using the typical features of a painting to refer to the painting itself is also a manifestation of metonymical thinking. The cultural symbol used here is also a figurative thinking based on specific cultural experience.

\subsection{Tools stand for works}

Chinese calligraphy is pleasant to look at.

The wide range of brush and ink, calligraphy and painting in the video has left an impression of Xi'an with profound history and culture on the audience. Han mo originally refers to writing brush and ink, which stands for the article, calligraphy and painting, belonging to the conceptual metonymy TOOLS STAND FOR WORKS. 


\subsection{Subevent stands for complex event}

In order to convey the idea of humanistic Xi'an, the video shows a scene of performing Shaanxi Opera (popular in the northwestern provinces of China) in costume. As a symbol of Shaanxi history and culture, Shaanxi Opera has long been well known to the audience. With the metonymy mechanism that parts refer to the whole, it represents the extensive Shaanxi culture, so the performance of Shaanxi Opera represents the inheritance of traditional culture. At the same time, the familiar images of young people riding and roller skating on the city wall also represent the traditional culture, which reflects that Xi'an citizens not only pursue a modernized lifestyle, but also actively embrace history and culture.

\section{Conclusion}

As a linguistic phenomenon, the generation and use of multimodal metaphors and metonymies in Xi'an City Image Promotional Video are influenced by the socio-cultural context and situational context, which is the embodiment of human cognitive mode. By studying the multimodal discourse of Xi'an City Image Promotional Video from the perspective of framing theory, it is hoped that a better understanding of the conceptual connotation, cognitive characteristics and operation mode of the multimodal metaphors and metonymies can be achieved. Meanwhile, the mechanisms and functions of the generation and understanding of metaphors and metonymies can be realized. Therefore, this study is conducive to creating a friendlier and warmer communication environment, improving the taste and aesthetic effect of the publicity discourse, gaining the conscious approval of the public, and shaping a positive and open city image.

\section{Acknowledgements}

This paper is the periodical achievement of The Scientific Research Project of Xi'an Peihua University: A Study on the Cognitive Construction of the Official Discourse System in Building the International Metropolis of Xi 'an under the "One Belt And One Road" Strategy with the Project number of PHKT18028.

\section{References}

[1] Lv Yuanyuan. A Critical Discourse Analysis of Xi'an International Horticultural Exposition Propaganda Film [D]. Shanghai International Studies University, 2012.

[2] Huang Shujun. Translation on City Promotional Video Based on Eco-translatology- A Case Study of Wuhan Promotional Video the Rise of a Great City [J]. Journal of Yangtze University (Social Science), 2016(3): 70-73.

[3] Pan Yanyan. The Cognitive Mechanism of Multimodal Discourses:a Case Study of the Documentary China's National Image Promotion: Perspectives [J]. Foreign Languages Research, 2013 (1): 10-19.

[4] Goffman, E. Frame Analysis: An Essay on the Organization of Experience [M]. Cambridge: Harvard University Press, 1974.

[5] Fillmore, C. J. Frame Semantics [C]. Soeu: Hanshin, 1982.

[6] Lakoff, G. The Neural Theory of Metaphor [M]. Cambridge: Cambridge University Press, 2008.

[7] Yuan Hongmei, Wang Shaohua. A Metaphorical Framing Analysis of American Political Discourse on Economic Issues-With Reference to US Presidential Election Debates between Obama and Romney in 2012 [J]. Foreign Language and Literature Studies, 2016(1): 8-19.

[8] Qiu Ying-ying. A Research on Multimodal Metaphor and Frame of City Image Taking City Image Promotional Films of Jiangsu as an Example [J]. Journal of Jinling Institute of Technology 
(Social Science), 2017 (2): 22-26.

[9] Zhang Wei, Wang Shaohua, Zhang Song-song. A Multimodal Metaphorical Frame Analysis of "The Slogan Promotion of 2014 Nanjing Youth Olympic Games [J]. Journal of Jinling Institute of Technology (Social Science), 2014 (3): 83-88. 